\title{
Tardy Presents: Embodied Agency in the "Documental" Poetry of Benjamin Péret and Antonio Porchia
}

\author{
Piet Devos and Gys-Walt van Egdom
}

The following pages examine an often overlooked literary tradition, which, in search of new footing, came to see the act of writing as a way of documenting subjectivity. This tradition does not include types of life writing that have been presented, throughout history, as unique, intentional products of subjective expression, such as autobiographies, diaries and letters. On the contrary, its rebellious proponents have attempted to purge literature of this expressive and intentional foundation.

One of its forerunners was Arthur Rimbaud, who dealt an important blow to traditional poetry by prioritizing the objectification of poetic forms. In his famous letter to Izambard, he scornfully dismissed the insipid sentimentalism of his mentor and urges poets to rely entirely on the evocative powers of language itself. ${ }^{1}$ Ultimately, these radical words resulted in the hallucinatory imagery of the Illuminations. It was believed that visionary trips revealed much more about the poet's creative powers than any deliberate act of confession. A few decades later, the modernists and historical avant-gardes would take this Rimbaldian priority of objectifying form to its limits, thus bringing literature closer than ever before to documentary activity. By including pictures, newspaper clips or advertisements in their texts, these writers uncovered that subjectivity is sometimes reducible to being the mere effect of haphazardly juxtaposed "fragments of the real".

Moving beyond the descriptions of such impersonal linguistic Potenzierungsmechanismen (or "mechanisms for potentiation") and montages, this essay will focus on experimental forms of literature that continue to presuppose human experience, while at the same time eradicating traditional notions of subjectivism. Concretely, it seeks to analyse, formulate and compare the poetics of Benjamin Péret and Antonio Porchia with the aim of illustrating how and to what extent their respective crusades against traditional subjectivism have

1 Arthur Rimbaud, Lettres du voyant, ed Gérald Schaeffer, Geneva, Droz, 1975, 112. 
turned their poetry into poetic documents, testifying of nothing less than "raw" or "pure" embodied agency. Given the diverging attitudes of Péret, a surrealist, and Porchia, a literary lone wolf, toward the documentary practice of writing, both authors will first be discussed separately. In the end, this discussion hopes to prove fruitful for a more complex grasp of documental agency in literature.

The paper will first introduce the author Benjamin Péret and his experience of écriture automatique, to move then to Antonio Porchia and the écriture acousmatique. The choice to analyze the work of Benjamin Péret is related to the fact that the author's work is an example of automatic writing in the early '20s, which aroused the interest of the surrealists. According to them, the automatic writing transforms writers into documentalists of the obscure side of their own personalities and becomes an original and innovative way to make literature a documental instrument.

The choice to study and present as well Porchia's work is related to the reach and mutual connections between Porchia and the surrealists. These connection open the way to reflect upon the documental status of his work.

In the third and final chapter the differences in the documental status of Péret and Porchia's oeuvre are analyzed in order to underline how the launch of the écriture automatique/acousmatique alters the status of the text, which is no longer merely a document, but becomes the true documentalist.

In his seminal essay on surrealism, Walter Benjamin stated that whatever André Breton and his companions produced could be anything but literature. "[T]he writings of this circle are (...) demonstrations, watchwords, documents, bluffs, forgeries if you will, but at any rate not literature", he claimed. ${ }^{2}$ The surrealists would not have disagreed with the German critic on the non-literary status of their writings, yet they would certainly reject most of his alternative descriptions to maintain the label of "documents". They indeed pretended to do nothing more than document their lived experiences of dreams, rambles through the city, and their collective games and discussions. This obsession with documentation is for instance reflected in their magazines, such as $\mathrm{La}$ révolution surréaliste (1924-1929), and would also result in the founding of their "Bureau de recherche" at the Rue de Grenelle in Paris. At this Bureau they

2 Walter Benjamin, "Surrealism: The Last Snapshot of the European Intelligentsia", in Selected Writings, eds Michael W. Jennings, Howard Eiland, and Gary Smith, Cambridge, MA, Harvard University, 2002, II, 208. 
kept a record not only of the group's activities but also of dream stories that the public could hand in. ${ }^{3}$

It was this "materialistic, anthropological inspiration" of lived experience that, in Walter Benjamin's view, distinguished surrealism from exclusively literary movements. ${ }^{4}$ Whereas literary or artistic creation had usually bestowed a distancing form on the represented world, in surrealist texts just like in kitsch "the world of things advances on the human being; it yields to his uncertain grasp and ultimately fashions its figures in his interior". ${ }^{5}$ In other words, surrealist texts seemed to bear witness to a most intimate familiarity with material surroundings, covering each tangible object with affective, unreflected meaning. As a consequence, for Benjamin the similarity between surrealist literature and the "banality" of dream imagery is most obvious: "It is the last mask of the banal, the one with which we adorn ourselves, in dream and conversation, so as to take in the energies of an outlived world of things". ${ }^{6}$ But how was this allegedly immediate bodily experience exactly documented in surrealist texts and why was this documentation needed?

As announced in the introduction, these issues are addressed by focusing first on the poetics of Benjamin Péret (1899-1959). Péret has often been regarded as Breton's most faithful lieutenant, but such a view does not do any justice to his lifelong, original contribution to the surrealist project as a whole. ${ }^{7}$ Central to his poetics was the notion of "la chair" (the flesh), which refers to embodiment, including both kinaesthesia (movement, body position) and the inner perception of sensations of desire or hunger. According to Péret, the flesh constituted the actual engine of all creative thinking; it was undeniably suppressed, however, by bourgeois rationalism and Catholic morality. In order to give the flesh the lead in literary production, he and other surrealists made use of the so-called "écriture automatique". Péret was an ardent practitioner of such automatic writing from the early 1920 s onward. However, his first theoretical piece on this practice was written during his stay in Brazil around 1930. There, he tried to propagate surrealist poetics through a series of articles in local newspapers.

3 Cf. La Révolution Surréaliste, Paris, Place, 1924-1929. Gérard Durozoi, Histoire du Mouvement Surréaliste, Paris, Hazan, 1997, 69-70.

4 Walter Benjamin, "Surrealism", 209.

5 Walter Benjamin, "Dream Kistsch", in Selected Writings eds. Michael W. Jennings, Howard Eiland, and Gary Smith, Cambridge, MA, Harvard University, 2002, II 4-5.

6 Walter Benjamin, "Dream Kitsch", 5 .

7 The most convincing overviews of Péret's career are still to be found in Jean-Christophe Bailly's Au-delà du Langage: une Étude sur Benjamin Péret, Paris, Losfeld, 1971, and Julia Field Cositch The Poetry of Change: A Study of the Surrealist Works of Benjamin Péret, Chapel Hill, University of North Carolina, 1979. 
In one of these articles, he explained to his bourgeois audience how they could free their minds of rational control and become real surrealist poets:

Prenez une main, du papier, de l'encre et un porte-plume avec une plume neuve et installez-vous confortablement á votre table. ... Ecrivez le plus vite possible pour ne rien perdre des confidences qui vous sont faites sur vous-même. ... Vous remarquerez bientôt qu'au fur et à mesure que vous écrivez, les phrases viennent plus rapides, plus fortes, plus vivantes. ${ }^{8}$

Take a hand, some paper, ink and a penholder with a new pen. Sit down comfortably at your table. ... Write as fast as you can, so you will not lose any of the confidences about yourself that are going to be shared with you. While you are writing, you will notice that the sentences are coming faster, with more intensity and vividness.

As the strangely depersonalized hand suggests, one has to forget about one's own identity while writing automatically and let oneself go with the flow of images that the words evoke. Péret assures his readers that the sentences that the hand scribbles down will plunge them into a marvellous, dream-like world that is completely different from the misery of daily life. In accordance with Breton's statements in the First Surrealist Manifesto, one can say that this automatic writing was for instance inspired by Freud's "talking cures", aiming at releasing all kinds of unconscious desires and fears. Yet this practice is not all there is to the story. For the interest in automatic movement was of little importance to psychoanalysis, as Freud had founded his new school in opposition to the deterministic belief in such psychosomatic mechanisms. As Manfred Hilke contends, real interest in automatisms was instead shown by experimental psychologists. ${ }^{9}$ An authority in the psychological debate, Pierre Janet, had reached the conclusion that habitual automatisms such as dancing, speaking or writing can be performed not so much unconsciously but instead distractedly, without paying attention to them. ${ }^{10}$

What the surrealists attempted to attain by means of the écriture automatique was indeed an extremely distracted mindset, in which they could rely entirely

8 Benjamin Péret, CEuvres Complètes, Paris, Association des Amis de Benjamin Péret/Librairie José Corti, 1987, IV, 245-6.

9 Manfred Hilke, L'Écriture Automatique: das Verhältnis von Surrealismus und Parapsychologie in der Lyrik von André Breton, Frankfurt am Main, Lang, 2002, 87.

10 Pierre Janet, L'automatisme psychologique. Essai de Psychologie Expérimentale sur les Formes Inférieures del' Activité Humaine, Paris, Félix Alcan, 1921, 28-9. 
on the kinaesthetic skill of their writing hand and become documentalists of the obscure side of their own personalities. Thus, writing had been transformed from an act of thoughtful composition into a documentary practice promising the immediate, albeit symbolic, registration of potentially unpleasant truths. The surrealists were convinced that whatever an automatic text revealed, it was always bound up with desire. It showed the otherness within oneself, or as Péret put it in a much later essay, "le sentiment inné de [l']insuffisance individuelle" that was so clearly at odds with the notion of a unified, rational subject."

In response to that "innate feeling of insuffiency", Péret developed a theory of "sublime love", similar to Breton's "amour fou", which was based on the romantic belief that every individual will be united with his or her true love at some point. However, since no one has the slightest idea when this will happen or with whom, it would be senseless to yield to the temptation of searching for one particular person. It is far better to simply wait for the marvellous encounter, as one will recognize one's "sublime love" from the image unconsciously carried along. We cite the following poem "Écoute" ("Listen") from Péret's 1936 collection Je sublime ("I sublimate"):

Si tu m'abritais comme un hanneton dans un placard hérissé de perce-neige colorés par tes yeux de voyage au long cours

lundi mardi etc ne seraient plus qu'une mouche sur une place bordée de palais en ruines d'oú sortirait une immense végétation de corail et de châles brodés oú l'on voit des arbres abattus qui s'en vont obliquement se confondre avec les bancs des squares oú je dormais en attendant que tu viennes comme une forêt qui attend le passage d'une comète pour voir clair dans ses fourrés qui gémissent comme une cheminée appelant la bûche qu'elle désire depuis qu'elle bâille comme une carrière abandonnée et nous grimperions comme un escalier dans une tour pour nous voir disparaitre

11 Benjamin Péret, QEuvres Complètes, Paris, Association des Amis de Benjamin Péret/Librairie José Corti, 1995, VII, 262. 
au loin

comme une table emportée par l'inondation ${ }^{12}$

If you sheltered me like a beetle in a cupboard / strewn with snowdrops which have the colour of your eyes / of long-distance travelling / then Monday Tuesday etc. would be nothing more than a fly / on a square surrounded by ruined palaces / from which profuse vegetation of coral and embroidered scarves would shoot / where one sees / chopped trees falling down / getting entangled with the public benches / where I slept awaiting your arrival / like a forest that awaits the passage of a comet to see clear / in its undergrowth groaning like a chimney / calling for a log for which it has been yearning ever since it is gaping / like an abandoned quarry / and we would ascend like a staircase in a tower / to see us vanish / in the distance / like a table carried away in the flood.

Quoting this poem at length shows how it is characteristic of the fact that the documentation of the desiring flesh is also reflected in its theme and structure. In this case it is also worth noting that in surrealist writing, according to Walter Benjamin, objects are drawn into the nearness of the subject's body. In this poem, an intricate relation is established between subjects and objects: the "I" is connected to the "you"; the speaker's inner world is interlinked with the surrounding environment e.g. his tactile needs of warmth and intimacy are projected onto the chimney, the stone quarry. Moreover, the stable identity has been replaced by the fleetingness of endless metonymy: the speaker is like a forest where the undergrowth moans like a chimney. The reader feels the rhythm of the continuously writing hand or the constant renewal of desire, that "sovereign phoenix that endlessly rises up from its own extinction", to put it in Péret's own terms. ${ }^{13}$ Considering Maurice MerleauPonty's observation that climbing in poetry and dreams is spatially modelled on bodily processes, such as breathing or lovemaking, then one might interpret the final scene of the "we" climbing the tower as a depiction of a sexual climax. ${ }^{14}$

In general, then, a surrealist poem like "Écoute" is not built on the linear continuity of rational consciousness but on the cyclical immediacy of embodied experience. Critics have often raised the question how authentic these automatic texts were. ${ }^{15}$ Do they truly (re)present "documents" of the desiring

12 Benjamin Péret, OEuvres Complètes, Paris, Association des Amis de Benjamin Péret/Librairie José Corti, 1971, II, 132.

13 Ibid., VII, 42.

14 Maurice Merleau-Ponty, Phénoménologie de laPperception, Paris, Gallimard, 1945, 329.

15 Cf. Michel Murat and Marie-Paule Berranger eds., Une Pelle au Vent dans les Sables du Rêve: Les Écritures Automatiques, Lyon, Presses universitaires de Lyon, 1992, 25. 
flesh, or are they just "forgeries"? Whatever one's opinion, the truth will remain unverifiable. More relevant from a historical point of view, therefore, is that - inspired by psychology - the surrealists forged a new myth of literary agency as the immediate documentation of the desiring flesh. Several friends of Péret remember that when the poet was once shown poems that he himself had written many years before, he had said: "Oh, that's really not bad at all! Who's the author?" ${ }^{16}$ Regardless of the veracity of this event, this anecdote is illustrative of the surrealist poem's status as a tardy document of a "present" that is not consciously memorized by the documentalist, but only lived, performed and afterwards forgotten. Writing as keeping record of true embodied living: this idea would keep on inspiring authors who, just like the surrealists, sought alternatives to Western rationality.

\section{Antonio Porchia: Écriture Acousmatique}

This section deals mainly with the notions of physicality and temporality in relation to selfhood in Antonio Porchia's writings so as to facilitate subsequent discussion of the documental status of his poetry. First, a general overview provides the characteristic traits of these writings. This survey is all the more useful, since the Argentine writer seems to have fallen into oblivion. Having provided such an overview helps to clarify why Porchia's oeuvre epitomizes what, by way of variation, can be called "écriture acousmatique". The essay then turns to notions even more central to its thesis and, doing so, necessarily stresses the kinship between Porchia's poetry and Taoism. Elaborating on this kinship makes it further possible to extract the documental status of "acousmatized" poetry.

The connection between Porchia (1885-1968) and surrealism has always been an object of interest. One could say that this is a direct result of the admiration of the surrealists for his work. In 1949, after the publication of a French translation of his poem-sentences, Porchia was invited to enter into a discussion with surrealist writers in France. He turned down the invitation by stating that "everything [of need] is already here [in Argentina]". ${ }^{17} \mathrm{~A}$ few years later, in 1952, reverence is paid to his poetry once more, when Breton indicates that the subtlest thoughts in Spanish have been uttered by him. ${ }^{18}$

16 Claude Courtot, Introduction à la Lecture de Benjamin Péret, Paris, Le Terrain Vague, 1965,6 o.

17 Daniel Gónzalez Dueñas and Alejandro Toledo, “Introducción", online: www.antonioporchia .com.ar/nueva/ensayos.php?id=1. 
However, this appreciation for his work does not entail the conclusion that the Argentine should be qualified as a surrealist. In an interview, Porchia himself states that he could not be indiscriminately lumped together with surrealist artists. Yet this statement must not be interpreted as resistance to surrealism. In fact, he enigmatically adds, "I don't know how to define myself because I am never myself". These few phrases sum up the artistic undertakings of Porchia: with this wordplay, he simultaneously distinguishes himself from surrealism ("I am not located in surrealism"), demonstrates that this distinction is not simply due to a twist of fate but a result of his ontological status ("I am never myself"), and, ultimately and paradoxically, adheres to surrealism (for, we can discern the voice of none other than Arthur Rimbaud, the spiritual father of surrealism, who maintained that "I is an-other").

Instead of forcing Porchia into or helping him out of the surrealist framework, emphasis continually needs to be placed on these artistic undertakings, for instance, by putting the aforementioned outcome of a simple ars combinatoria "No soy nunca yo" into context. This phrase could well have been one of the 1,182 poem-sentences Porchia published during his lifetime. In this phrase Porchia displays a technique that he uses frequently in his Voces, his only literary work. ${ }^{19} \mathrm{He}$ isolates two identical terms and presents them as contradicting terms. But a few, from among countless examples, can be given here:

(1) No sale de lo malo quien está en él, porque teme encontrarse ... con lo malo.

(2) Tu dolor es tan grande que no debiera dolerte.

(1) One who dwells in evil doesn't leave, for fear of running into ... evil.

(2) Your hurt is so great that it shouldn't hurt you.

This technique can be opposed to another frequently deployed writing technique, consisting in the establishment of a relation of identity between (naturally, cognitively or contextually) opposing terms:

(3) Hallarás la distancia que te separa de ellos, uniéndote a ellos.

(4) Todo es un poco de oscuridad, hasta la misma luz.

19 Many editions of Voces appeared since 1943, the year of the first publication of the poemsentences - 1948, 1956, $1964 \ldots$ - some were released under similar yet different titles, some contained but a selection of the original poem-sentences, other were replete with completely new voices. We have made use of the website dedicated to Antonio Porchia, where all editions have been compiled, sorted and even translated into English: http:// www.antonioporchia.com.ar. 
(3) You will find the distance that separates you from them, by joining them.

(4) Everything is a bit of darkness, even light itself.

Both techniques are deployed to show the reverse sides of the same coin. The reader is confronted with an excess or a lack that undermines a postulated identity (examples 1-2). This confrontation has a profound effect on the reader, who realizes that traditional dichotomies constitutive of Western (self/Other, mind/matter) thought might lack solid ground or exceed their own grounds as well. At the same time, however, the reader is comforted by the author, who argues that everything forms a part of a continuity and that it is only in this constant flow of energy that the ever-merging Oneness or self can emerge (examples 3-4). The self has thus been transformed in the writing and reading process. It has been freed from all necessity and everything it has needlessly clung to - for it could well have been otherwise or positioned elsewhere. The new and true Self is utterly self-less and at the same time all-encompassing. This nature is why Porchia's own reflection on the explicit biographical content of his Voces boils down to the remarkable statement that Voces is not only his own biography; rather, one has to conceive it as almost everyone's: the authorship of the Voces could be attributed to n'importe qui. ${ }^{20}$

These reflections, therefore, provide sufficient reason to claim that Voces is the product of an écriture acousmatique. The adjective "acousmatique" has already been employed in music theory to refer to sounds that lack a bearer, a definable origin. ${ }^{21}$ "Acousmatized" sounds dwell in a ghostly twilight, between bodies, sometimes in search of them. In the case of the Porchia's voices, though, they do not necessarily long for the body of the writer: they content themselves with finding the reader whose voice is ever so similar to their own. Our point is proven by Jorge Luís Borges, who selected three poem-sentences at random and commented on the way these voices seemed destined to reach him - and only him. ${ }^{22}$ The fact that the voices lack substance and seem to resonate eternally, on a spiritual plane, has led additional, earlier readers to believe that there was an intricate connection between Voces and (among other thinkers) Lao Tzu, La Rochefoucauld, Novalis. ${ }^{23}$ All these connections fail to fit

$20 \quad$ Inés Malinow, "No Busco la Poesía; Viene a Mí”.

21 Pierre Schaeffer, Traité des Objets Musicaux, Seuil, Paris, 1966, 91.

22 Jorge Luís Borges, "Voix: Prólogo", online: www.antonioporchia.com.ar/nueva/ensayos .php?id=3.

23 Borges; "Voix: prólogo". Daniel Gónzalez Dueñas and Alejandro Toledo, "Introducción", online: www.antonioporchia.com.ar/nueva/ensayos.php?id=1. Alicia Dujovne Ortiz, "Voces "del Silencio", www.antonioporchia.com.ar/nueva/ensayos.php?id=4. 
the picture of reality, however, given that the author had not been familiar with their ideas. Still, the fact that these voices sprung out of an intellectual vacuum does not automatically imply that we are dealing with creations ex nihilo, i.e. that they are not a product of something. Above all, they remain the product of human experience.

Here, having stressed that Porchia's oeuvre refuses anchorage in literary tradition leads to a critical moment in the analysis at hand. In that his writing fails to occupy any fixed position, it seems imperative to contextualize this oeuvre by referring to Porchia's life. In fact, this approach is suggested by the author himself, for it calls to mind his statement that the poem-sentences are autobiographical (as well as biographical). The fruitfulness of this approach can be highlighted, moreover, by referring to testimony from Porchia's niece, Nélido Orcinoli. She stressed that, despite appearances, it had taken her uncle a lot of time to write each voice: the meticulously written poem-sentences were always charged with personal life experience. ${ }^{24} \mathrm{~A}$ poem-sentence in which the writer depicts his affection for a prostitute supports the niece's story: "Hallé lo más bello de las flores en las flores caídas" ("I found what is most beautiful in flowers in a fallen flower"). ${ }^{25}$

However, resorting to biographism cannot prove useful to this discussion since, as already mentioned, acousmatic writings do not require a definable origin. So, how can one avoid being deadlocked here? Can biographism, ever reliant on insights in the author's personal endeavours, be kept at bay and the present argument still invoke the notion of experience? Formulating a consistent answer for these questions, in fact, only requires comparing his oeuvre to the lines of thought it is said to espouse closely: those of Eastern philosophies. Given the scope of this article, it seems sensible to concentrate only on Taoism at present and to avoid a broad inquiry into the history of this philosophy/ religion. For now, may it suffice to note that this line of thought encourages its followers to reject the whims of man, even the philosophical urge to obtain knowledge, and of the world, thus walking in the way of Tao. ${ }^{26}$

24 Daniel Gónzalez Dueñas, "Semblanza", Online: http://www.antonioporchia.com.ar/sp/ bio.php.

25 González Dueñas and Alejandro Toledo, "Introducción”.

26 Among countless other options, we have opted for the (demystifying) translation of Giafu Feng, who elegantly translated the following negative prescript of Taoism: "Empty yourself of everything./Let the mind become still./The ten thousand things rise and fall ..../ They grow and flourish and then return to the source..../ Being at one with the Tao is eternal./And though the body dies, the Tao will never pass away". Lao Zu, Tao Te Ching, online: http://www.geekfarm.org/cgi-bin/tao.pl?translation=feng. 
With this comparison, notably both Porchia's oeuvre and Taoism dismiss the effectiveness of rationality: they are aware that the rationalist tendency to determine or discriminate is nothing but a "devilish" inclination. ${ }^{27}$ As a consequence of this awareness, a space opens up for a paradoxical thought which affirms the "indiscriminate" identity of the One - Taoists refer to this oneness as the source of the flow of life $(c h i){ }^{28}$ The refusal of categorization eventually leads to the disintegration of the self. Porchia's critics who insist on the kinship between the Voces and Eastern philosophy have failed to take this crucial disintegration into account: to them Porchia is still considered a full-fledged author, one with a stable identity who registers his personal experiences.

What is certainly striking, however, is that, in Taoism, the disintegration of the conceptual world gives rise to something called "pure experience". After having obtained insight into the relativity of the Ten Thousand Things (Wan $w u$ ), and having rid being of traditional selfhood, man reaches his essence and becomes capable of (non-metaphorical) reflection: "The Perfect Man uses his mind like a mirror - going after nothing, welcoming nothing, responding but not storing". ${ }^{29}$ Yet, one hastens to add, the true self, despite being compared to nothing less than a baby and uncarved wood - both accurate translations of the pinyin word "p'u" - can only arise out of the ashes of old selfhood. ${ }^{30}$ For even though the essence of being has always been a given, it remains a product of (lived) experience: the old self has to take up the challenge of sticking to the strict negative precepts of emptying himself and "let the mind become still". At this point, it is possible to acknowledge that experience need not rely on an experiencing entity, and that the acousmatized voices can remain the product of experience without being exclusively attached to Porchia's experience.

What does this comparison with Taoism reveal about central notions of physicality and temporality? By dint of comparison, it has been possible to reveal that and exactly in what way écriture acousmatique is rooted in pure experience. At the same time, it has been made clear that the ideal of pure experience presupposes a complete annihilation of subjectivity: it renders all traditional Cartesian tenets obsolete. However, the desubjectivized "agent", to whom the acousmatized writings are attributed, has no need to substitute

27 Dujovne Ortiz, "Voces del Silencio".

28 "The Tao begot one./One begot two./Two begot three./And three begot the ten thousand things.//The ten thousand things carry yin and embrace yang./They achieve harmony by combining these forces". Lao Tzu, Tao Te Ching.

29 Chuang Tzu, The Complete Works of Chuang Tzu, New York-London, Columbia University Press, 1968, 97.

30 "He who has virtue is like a newborn child". Lao Tzu, Tao Te Ching. 
these Cartesian tenets for an irrationalist belief, celebrating motility and desire: Porchia's writings display serenity and lucidity. ${ }^{31}$ Therefore, it seems superfluous to point out that this serenity is a product of a very particular bodily experience. Precluding rationality as well as desire, the author strongly affirms the simple Being-there of the experiencing body (Dasein). This simple corporeality, in a paradoxical manner unmediated by the autonomous or pathological mind, generates the sense of serenity typical of Voces; body and mind have become one and give in to the contingency of being. However, it also produces a sense of perenniality: relieved of what Porchia himself called the "beggarly will to live", the selfless self experiences life to the fullest.

By way of closing this section, an initial attempt can be made at defining the documental status of Porchia's poem-sentences. In light of the specific sense of temporality and physicality discussed above, it seems justified to claim that the acousmatic writings of the Argentine are not bound by time, that they show glimpses of eternity. By mirroring life as such, the poem-sentences are nothing less than concise documents of a perpetually renewing or "presencing" present.

\section{Conclusion}

This conclusion, then, again addresses its essay's initial question regarding the difference in the documental status of Péret's and Porchia's oeuvre. In order to formulate an answer to this question, it is worth pointing out a striking similarity between both authors. What Péret as well as Porchia actually tried to do was to use the literary text as a way of documenting some kind of selfhood that no longer fit within the stable categories and binary oppositions of Western thought. For them, the self could no longer be clearly distinguished from the other, as in their view every subject was always replete with notions of alterity, the flesh and the pure experience of bodily energy, as the case may be.

However, these notions of alterity bring us to the crossroads where Péret's and Porchia's ways do indeed diverge. Surrealists like Péret aimed at making the body speak up in the text, to register its desire and its suffering in the automatic flow of words. This aim was part of their particular cultural and political agenda: during the intellectual and social crises of the interwar years,

$31 \quad$ Here we should add the following voice to dispel all doubt regarding the ties of Porchia to Surrealism: "Creen que moverse es vivir. Y se mueven, no para vivir. Se mueven para creer que viven" ("They believe that moving equals living. And they move, not to live. They move to believe that they are living"). 
they placed a high priority on the disclosure of new ways of living nurtured by affective energy (rather than by instrumental reason). Antonio Porchia, on the other hand, attempted to transcend personal bodily experience. During the writing process, the author did not rely on any kinaesthetic automatism but resorted to a pseudo-Eastern mode of meditation, which had to free the writer from earthly desires. Consequently, he refused to strive for any kind of artistic or social goal. Nonetheless, by means of Voces the reader is shown the route to a similarly liberating transcendental experience. As mentioned, these poemsentences inform Porchia's own as well as any(-)body's biography.

Péret's and Porchia's diverging attitudes toward the documentary practice of writing are reflected in their oeuvres. Whereas surrealist poems reveal the cyclical structure of a constantly renewed desire, of an intensely lived present never ceasing to repeat itself, the Voces resemble aphorisms that force desire even the desire to live - to fade away and help gain access to perennial wisdom. Both oeuvres are clearly at odds with the descriptive prose and linear time approach of the more objective documentation, idealized and dominantly present in traditional historiography.

Nevertheless, this opposition does not imply that the writings of Péret and Porchia are merely a document of subjective experience. As has been stressed repeatedly, both authors challenge the notion of subjectivity itself - albeit in dissimilar ways. In Péret's poetics, rationality gives way to affectivity, hitherto always smouldering beneath the surface without finding release. This shift results in the undoing of subjectivity, since affective energy confronts the self with its extimate core, a core that renders the distinction between the subject and the object impossible. In a way, one can say that in Péret's oeuvre the traditional subject explodes - its pieces are scattered over the surface of the objectal earth. Porchia, in his turn, not only rids the self of rationality, but even purges it of irrational affectivity, thereby causing subjectivity to implode - leaving nothing but an empty hole, perhaps the objectivized body as an experimental receptacle, in its place.

Despite repeatedly restated differences, both authors, in their respective attempts to thrust aside subjectivity, share a common interest in the significance of bodily agency: both oeuvres can be aptly described as (tardy) documents of a bodily present/presence. In this respect Péret and Porchia, sharing this crucial trait, can help redraw the contours of agency in the fields of document studies/historiography. In the past decades, it has become customary to attribute some kind of agency to the documental practice: on the emission side, the author is deemed to exert consciously a considerable influence on the depiction of reality; on the reception side, the documental material is manipulated by those in power - historiographers, policy makers 
and so on - given their hand in the selection and/or the interpretation process. The "documental" poetry of Péret and Porchia, too, grants agency an important role. Even so, as this essay has set out to prove, they did so by allowing the objectifying force of language to come into play, specifically, the documentary medium. With the introduction of écriture automatique/acousmatique, the text is no longer merely a document: it has become the true documentalist.

\section{Bibliography}

Bailly, Jean-Christophe, Au-delà du Langage: une Étude sur Benjamin Péret, Paris, Losfeld, 1971.

Benjamin, Walter, "Dream Kitsch", in Selected Writings, eds Michael W. Jennings, Howard Eiland, and Gary Smith, Cambridge, MA, Harvard University, 2002, II, 3-5.

Benjamin, Walter, "Surrealism: The Last Snapshot of the European Intelligentsia", in Selected Writings, eds Michael W. Jennings, Howard Eiland, and Gary Smith, Cambridge, MA, Harvard University, 2002, II, 207-221.

Borges, Jorge Luís, "Voix: Prólogo", online: www.antonioporchia.com.ar/nueva/ensayos .php?id=3.

Breton, André, OEuvres Complètes, Gallimard, Paris, 1999.

Chuang, Tzu, The Complete Works of Chuang Tzu, New York-London, Columbia University Press, 1968.

Courtot, Claude. Introduction à la Lecture de Benjamin Péret, Paris, Le Terrain Vague, 1965 .

Dujovne Ortiz, Alicia, “'Voces' del Silencio", online : www.antonioporchia.com.ar/nueva/ ensayos.php?id=4.

Durozoi, Gérard, Histoire du Mouvement Surréaliste, Paris, Hazan, 1997.

Field Costich, Julia, The Poetry of Change: A Study of the Surrealist Works of Benjamin Péret, Chapel Hill, University of North Carolina, 1979.

Gónzalez Dueñas, Daniel, "Semblanza”, online: http://www.antonioporchia.com.ar/ sp/bio.php.

Gónzalez Dueñas, Daniel and Alejandro Toledo, "Introducción", online: www .antonioporchia.com.ar/nueva/ensayos.php?id=1.

Gónzalez Dueñas, Daniel, "Borges y Porchia: el Aquí y el Ahora”, Revista de la Universidad de México, 48, (Februari 2008), 15-22.

Hilke, Manfred, L'Écriture Automatique: das Verhältnis von Surrealismus und Parapsychologie in der Lyrik von André Breton, Frankfurt am Main, Lang, 2002.

Janet, Pierre, L'automatisme psychologique. Essai de Psychologie Expérimentale sur les Formes Inférieures de l'Activité Humaine, Paris, Félix Alcan, 1921. 
Lao Zu, Tao Te Ching, online: http://www.geekfarm.org/cgi-bin/tao.pl?translation=feng. La Révolution Surréaliste. Paris, Place, 1924-1929.

Malinow, Inés, “'No Busco la Poesía; Viene a Mí’: Antonio Porchia” [English version], online: http://www.antonioporchia.com.ar/en/testimonios.php?id=14.

Merleau-Ponty, Maurice, Phénoménologie de la Perception, Paris: Gallimard, 1945.

Murat Michel, \& Marie-Paule Berranger, eds, Une Pelle au Vent dans les Sables duRrêve: Les écritures automatiques, Lyon, Presses Universitaires de Lyon, 1992.

Péret, Benjamin, CEuvres Complètes, Paris, Association des Amis de Benjamin Péret/ Librairie José Corti, 1971, II, 132.

Péret, Benjamin, CEuvres Complètes, Paris, Association des Amis de Benjamin Péret/ Librairie José Corti, 1987, IV.

Péret, Benjamin, CEuvres Complètes, Paris, Association des Amis de Benjamin Péret/ Librairie José Corti, 1995, VII.

Pierre Schaeffer, Traité des Objets Musicaux, Seuil, Paris, 1966.

Porchia, Antonio, Voces [Spanish \& English Version], online: http://www.antonioporchia .com.ar.

Rimbaud, Arthur, Lettres du Voyant, ed Gérald Schaeffer, Geneva, Droz, 1975. 